\title{
THE CURRENT STATE OF CSR IN THE FOOTBALL CLUBS OF THE PROFESSIONAL FOOTBALL LEAGUE IN JORDAN
}

\author{
Yehia Al-Daaja ${ }^{1}$ - György Norbert Szabados ${ }^{2}$ \\ ${ }^{1}$ University of Debrecen Faculty of Economics and Business 138 Böszörményi Street, Debrecen-4032 Hungary \\ e-mail: albwairy@yahoo.com \\ ${ }^{2}$ University of Debrecen Faculty of Economics and Business 138 Böszörményi Street, Debrecen-4032 Hungary \\ e-mail: szabados.gyorgy@econ.unideb.hu
}

\begin{abstract}
Corporate Social Responsibility (CSR) has become a common practice all over the world, however, social responsibility in the field of sport is still a new concept and received a little attention. This study aims to reveal the current state of social responsibility practices among the football clubs of the professional football league in Jordan. A descriptive survey method was used and a questionnaire was designed to collect the required data on three aspects (administrative, financial and CSR programs). The study found that there is a medium degree of availability of the administrative and financial aspects that activate the implementation of the CSR concept. Moreover, the study also revealed a medium degree of availability of the CSR programs offered by the selected clubs. Furthermore, the study proved that the football clubs in Jordan are aware of their social responsibility and recognize their role in the betterment of the society.
\end{abstract}

Keywords: Corporate Social Responsibility, Football Clubs, Sports, Jordan.

(JEL Classification: Z29, M14, Z20, M10, L20)

\section{INTRODUCTION}

\subsection{An approach to CSR}

Corporate Social Responsibility (CSR) has become a common practice all over the world. According to MISENERMASON, (2006) social responsibility practices related to sports could be linked to community development, however, there is a great scarcity of studies of social responsibility in the field of sports, and it is still a new concept and received a little attention in CSR literature (ROSCO, 2011). According to some scholars it is related to the common understanding that sport is just a mere hobby (AKANSEL ET AL, 2010), and the lack of financial support which causes a limited value of sport as a vehicle for social responsibility (SMITH \& WESTERBEEK, 2007). Consequently, "the CSR in sports has been largely neglected " ZEIGLER (2007). There is a need for a better understanding of corporate social responsibility practices in the sports field and investigate how sports can play a major role in bridging the gap between economic and social issues, (ZEIGLER, 2007).

The main idea of CSR is that business and society are interwoven rather than distinct entities, however, the sports clubs considered as a unique business organization, because they are being both social and economic institutions, they are well-suited to have a socioeconomic framework that contained business principles and CSR practices (SHETH \& BABIAK, 2009; SMITH \& WESTERBEEK, 2007). The United Nations identified sport as a powerful tool for strengthening social ties and networks, and for promoting the ideals of peace (UNITED NATIONS, 2005). The football game considered as one of the most popular sport in the world, therefore the football clubs should use the passion for this game as an anchor that meet the 
aspirations of the people and motivate them to participate in various CSR initiatives and translate the CSR in all its aspect to serve the human being and society. In this context, this study aims to reveal the social responsibility practices in the football clubs of the professional football league in Jordan, through a comprehensive approach that investigates the degree of availability of the administrative and finical aspects and the programs offered by the selected clubs beside identifying its strengths and weaknesses, to promote its role in the field of social responsibility and improve its future initiatives.

The three aspects of the study were chosen on a scientific basis, where the Meras Center for Management Consultancy in his guidelines manual for policies and procedures of social responsibility programs have pointed out that the process of developing the CSR programs in business organizations is summarized in three stages: the planning stage, the implementation stage, and the follow up process stage, which includes the measurement and continuous improvement. However, all the stages should be accompanied by a vision and mission and set of goals for CSR that fit with the organizational structure. Furthermore, the organization should determine its financial ability, its products, and services that support its CSR initiatives. In addition, the guidelines manual includes information about the evaluation process for the current CSR programs (MERAS CENTER FOR MANAGEMENT CONSULTANCY, 2010).

According to the researcher knowledge the CSR practices in the Jordanian football clubs have not been investigated before, thus, this study will be the first which examines the CSR practices in the football clubs and provide a precise description of the CSR practices in the football clubs in Jordan, as well as, open the way for further CSR research and studies in the sports field on all levels. In addition, it will help the Jordanian sport clubs to promote CSR practices and, help the decision makers to improve the role of social responsibility in those national institutions. Furthermore, this study attempts to answer the following main question: what is the current state of the social responsibilities practices in the football clubs of the professional football league in Jordan, from the point of view of the board member's, administrators and players of the first football team?

\subsection{CSR in the sport context}

For decades, the CSR concept has been circulating in corporate boardrooms, but after a wave of criticism, and more of public pressure, new challenge has been created to the business climate and demand on business to behave ethically towards society and the surrounding environment, perhaps in response to this growing skepticism, some leading companies have publicly labeled themselves as socially responsible, and become more interested in spending on social problems (MAIGNAN AND FERRELL.2004). SCHWAB (Executive Chair, World Economic Forum) (2008, p. 107) stated that "Compared to just a decade ago, it is now common for business people to talk about social responsibility and the importance of being good corporate citizens". (SCHWAB, 2008).

In today's business environment, where companies have become global citizens, the world has witnessed new forms of corporate social responsibility, including the CSR in the sports fields. According to SMITH AND WESTERBEEK, (2007) the features of sports corporate social responsibility are: 1) Increase the communication power with the media, 2) Support youth participation, 3) Positive health effects, 4) Interaction with social life, 5) Increase awareness and cultural integration. Moreover, there were many driving forces behind the adoption of CSR in sports organizations, according to BABIAK AND WOLFE'S, (2009) there are different types of external forces, that play an important role in the adoption of CSR by professional sports teams such as constituents of the initiatives of other organizations, and more broadly the perceived expectations of society, beside an internal dimension, such as resources which play a major role in determining the adoption of CSR.

Hundred and fifty years ago, the churches in England had been the first who established soccer clubs to help the homeless people, youngsters, children, and teenagers, who were taken from the streets and brought to places next to the church's and provided with food, shelter and integrate them into their social lives by playing football. For example, clubs such as Everton, Aston Villa, Fulham or Southampton, established to serve social issues based on churches ethical and moral role in the society. By the beginning of 1887, in the era of the British Industrial Revolution, companies had set up special football teams to achieve a better use of their employees free time, and keep them away from the danger of an alcoholic community, in order to enhance their productivity, a particular example is West Ham United, a football club established in 1895 by Thames Ironworks in London. On the other hand, Football clubs, such as Manchester City, Blackburn Rovers or Nottingham Forrest have emerged from the pubs, where pubs owners organized football matches in order to satisfy their customers. Furthermore, the public schools were the first places for football and it was played in order to keep the pupils away from dangerous addictions, such as drinking or smoking and since then the game spread to the European continent and to all of the world (AKANSEL ET AL, 2010, ROSCA, 2011). Up to now, the sport has also become a business, in the center of which are the players themselves, and where talent and career management have a strong relationship (BÁCSNÉ (2015), HÉDER-DAJNOKI, (2017)).

In recent years, the football industry has emerged and football clubs have become an independent economic and social institution. BREITBARTH AND HARRIS (2008) indicated that soccer has become an industrial issue during recent years and influenced sports administrators to be more conscious in social-politic issues. Although professional soccer clubs today have historical significance, their social identities cause them to be seen as the real representatives of society. This characteristic facilitates soccer clubs to integrate with society and can increase the effectiveness of CSR activities. Consequently, football organizations increasingly use CSR activities to deploy their corporate brand in the eyes of their fans, spectators, and online consumers. Some clubs established their own charitable foundations that provided 
social services, others established a CSR department to fulfill their obligations to society. In addition, some famous players have established their own charitable institutions such as the B. Samuel Foundation and the Leo Messi Foundation Moreover, national federations and associations have launched some social responsibility programs such as the Turkish Football Federation and the English Premier League. On international level FIFA established its own Social Responsibly Department in 2005 (AKANSEL ET AL, 2010, ROSCA, 2011).

In the growing global interest in social responsibility, the sport is considered as an opportunity to improve the quality of life, it can work as a bridge to cross the social and economic gaps (SMITH AND WESTERBEEK (2007). Consequently, the national and international football clubs' federations started to realize their responsibility towards their societies through implementing distinctive CSR programs, projects and initiatives that enhance the community sustainability, for example, Barcelona Club allocated part of its income for the benefit of the Barcelona football foundation and implement some of the international development programs. Manchester United, with his foundation for charity, launched various social initiatives in fields like education and health. Researches and studies show that the European clubs, in particular, the English ones show their interest in social responsibility. For instance, the study of AKANSEL, ATES, TAPAN \& OZDEN (2010), which has conducted on 43 federations and 53 clubs in Europe, presented a group of clubs that have participated in many activities of social responsibility. In addition, there are some clubs in the middle east region that adopted the concept of social responsibility, for example Al Sadd Sport Club, which is a Qatari sport club that, in 2011 established the Social Responsibility Unit, and launched initiatives that supported the Qatari Federation for People with Special Needs and provide assistance to many local community institutions (AKANSEL ET AL, 2010, ROSCA, 2011).

\subsection{Sports in the Jordanian context}

In Jordan, as part of the global community, football has always been and remains the most popular sport in the country. According to the Jordanian football association "football is about the people; the players and the fans. It is a celebration of our culture. Our beliefs and our connection to the global community." (HTTP://WWW.JFA.COM.JO/EN/ABOUT/).

Football is considered as the most popular game in Jordan, and it receives great attention from various segments of the Jordanian people. The game practices run by Jordan football association, which is the governing body of football games in the country and administrate the national team as well as the national league. The Jordan football association cup is Jordan's premier knockout tournament in men's football (soccer) game, a Jordanian professional league for football clubs, known as Jordan Cup Al Manaseer after the FA (Football Association in Jordan) signed a sponsorship deal with Ziyad AL-Manaseer Companies Group. Jordan Professional League (AL-Manaseer) represents the top Jordanian football clubs, the championship consists of twelve competing teams in a home and away league system. The league is largely similar to that of the Scottish premier league or Spain's la Liga" (https://
en.wikipedia.org/wiki/Jordan_Premier_League).

The majority of logos of sports clubs in Jordan includes and demonstrate three words "social - cultural and sports club", which explained the meaning of the sports club as a "social-cultural and sports institution". According to the sports clubs' rules and Regulations that issued by the Jordanian Ministry of Youth in 2005, the sports club was defined as a Non-Governmental Organization that authorized to exercise and practice sports, cultural and social activities. It is legally established to achieve social goals that serve the whole society, therefore sports club understood in the Jordanian context as the institution that aims to promote good citizenship, through implementations of programs and activities that attached to the state goals and objectives (MINISTRY OF YOUTH, 2005).

Historically, and based on information published before 1946 by Jordanian newspapers, the first football club's establishment in Jordan was in 1928, it was called Jordan Sports Club, and then some of its members moved out and formed a new club called Prince Talal Club. Furthermore, in 1929 the Circassian Club was founded. However, the three clubs did not last long because most of their members were Jordanian students who left the country to peruse their education abroad. The club, which is considered as one of the first clubs which last long in terms of its appearance and participation, is al- Faisaly Club, which was established in 1932 and firstly called Al-Ashbal Club ,then changed its name to al- Faisaly Scout Club, and now it is known as al- Faisaly Club. (HTTP://WWW.ALFAISALYSCJO.COM).

The first league championship in Jordan was in 1944, where Jordan considered as the first of Arab and Asian countries that introduce an official football tournaments. Jordan Football Association (JFA) established in 1949 and soon joined FIFA in 1958, and in 1974 became a founding member of the UAFA (The Union of Arab Football Associations) and a member of AFC (Asian champion's league) in 1975. The JFA oversees all football tournaments and activities in Jordan, starting from the grassroots, center, official local tournaments, women's football and the men's football championships (HTTPS:// EN.WIKIPEDIA.ORG/WIKI/JORDAN_PREMIER_ LEAGUE).

\section{MATERIALS AND METHODS}

The study adopts a descriptive survey method, using a cross-sectional approach. In this research both primary and secondary data were used, the secondary data is used to obtain information about the CSR in sports, with respect to the football clubs in Jordan. Data was collected from journal articles, Ph.D. theses, books, and websites of CSR and sports fields. Regarding the empirical part of the research the primary data was collected in order to describe the opinion and attitudes of the respondents toward the CSR practices in the football clubs of the professional league in Jordan by using a structured questionnaire, built, developed and based on several questionnaires that were previously used in CSR research's as well as in other sports studies especially the study of AL-QARNY, (2014), (SAUNDERS, ET AL. 2009). 


\subsection{Study population and samples}

The study population consists of all board members and administrators and the first football team players of the 12 football clubs of the Jordanian professional league with a total targeted population numbered 513 . The sample was randomly selected, 240 responses have been attained in the statistical analysis process, with a ratio of $47 \%$ percent of the total targeted population. This high response rate was mainly due to the fact that the questionnaires were distributed to 12 clubs and were accompanied by oral communications from the sports clubs' directorate at the Ministry of Youth in Jordan and it was delivered and collected through its own official channels and supported by the potential efforts of the ministry employees.

Table 1: Study Population

\begin{tabular}{|c|c|c|c|c|c|c|}
\hline No & Club Name & City & $\begin{array}{l}\text { Board of } \\
\text { Directors }\end{array}$ & $\begin{array}{c}\text { Adminis- } \\
\text { trator }\end{array}$ & $\begin{array}{c}\text { Football } \\
\text { team } \\
\text { player }\end{array}$ & \multirow{13}{*}{ 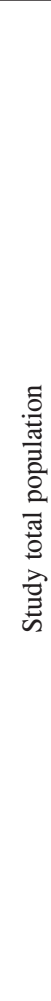 } \\
\hline 1 & Al-Faisaly & Amman & 9 & 4 & 30 & \\
\hline 2 & $\begin{array}{l}\text { Al-Hussein SC } \\
\text { (Irbid) }\end{array}$ & (Irbid) & 9 & 6 & 30 & \\
\hline 3 & Al-Ramtha SC & $\begin{array}{l}\text { Al- } \\
\text { Ramtha }\end{array}$ & 9 & 5 & 30 & \\
\hline 4 & Al-Jazeera & Amman & 9 & 4 & 28 & \\
\hline 5 & Al-Manshia & Al-mafreq & 11 & 6 & 25 & \\
\hline 6 & That Ras & Al-Karak & 7 & 5 & 24 & \\
\hline 7 & Al-Yarmouk FC & Amman & 7 & 5 & 27 & \\
\hline 8 & Al-Wehdat & AMMAN & 11 & 8 & 30 & \\
\hline 9 & $\begin{array}{l}\text { Shabab Al-Ordon } \\
\text { Club }\end{array}$ & Amman & 9 & 4 & 30 & \\
\hline 10 & Al-Baqa'a Club & Amman & 9 & 6 & 30 & \\
\hline 11 & $\begin{array}{l}\text { Al-Ahli Sports } \\
\text { Club }\end{array}$ & Amman & 9 & 8 & 30 & \\
\hline 12 & Al-Aqaba & Al-Aqaba & 7 & 6 & 26 & \\
\hline Tota & & & 106 & \begin{tabular}{|l|}
67 \\
\end{tabular} & 340 & 513 \\
\hline
\end{tabular}

Source: Ministry of Youth, 2017.

\subsection{Data collection method}

A questionnaire was used to achieve the study goals and have been distributed and collected from board members and administrators and players of 12 football clubs in Jordan for the year 2017. The questionnaire was fairly comprehensive, consisting of 49 items and distributed on three dimensions (administrative, financial \& programs offered) and investigating the degree of availability of administrative and financial factors that activate the CSR implementations in the club also, and examine the social responsibility programs provided by professional league clubs in Jordan from the perception of board members, administrators, and the players. The data for this research were collected from the selected clubs and subjected to an excel database, it was coded and analyzed using SPSS software.

\section{RESULTS AND DISCUSSION}

\subsection{Reliability Test (Cronbach's Alpha)}

Reliability is expressed as a coefficient and it ranges from (0.00-1.00) thus, if the coefficient is high this means the reliability is high and vice versa. Also, it refers to the degree that the aspect is offering constant data and free of accidental errors. Cronbach Alpha was used in this research to calculate the questionnaire's reliability.

Table 2. Reliability in the Scale's aspects

\begin{tabular}{|l|l|l|}
\hline ASPECTS & Number of Items & Cronbach alpha \\
\hline Administrative aspects & 23 & 0,91 \\
\hline Financial aspects & 11 & 0,80 \\
\hline Programs provided & 15 & 0,85 \\
\hline All & 49 & 0,94 \\
\hline
\end{tabular}

Source: Private edition, 2018.

\subsection{Respondents' demographic description}

The following results have been found after analyzing the collected data from the responding sample in terms of, years of experience, academic level and the type of relationship with the club.

Table 3: Sampling Distribution by Demographic Information

\begin{tabular}{|c|c|c|c|}
\hline Variable & Options & Frequency & Percentage \\
\hline \multirow{3}{*}{$\begin{array}{l}\text { Years of experi- } \\
\text { ence }\end{array}$} & Less than 5years & 56 & 23 \\
\hline & $5-10$ years & 113 & 48 \\
\hline & Above 10 years & 71 & 29 \\
\hline \multicolumn{2}{|l|}{ Total } & 240 & 100 \\
\hline \multirow{3}{*}{ Academic Level } & $\begin{array}{l}\text { Less than Bachelor } \\
\text { Degree }\end{array}$ & 117 & 49 \\
\hline & Bachelor Degree & 91 & 38 \\
\hline & High- Level Degree & 32 & 13 \\
\hline \multicolumn{2}{|l|}{ Total } & 240 & 100 \\
\hline \multirow{3}{*}{$\begin{array}{l}\text { The type of the } \\
\text { relationship } \\
\text { with the club }\end{array}$} & $\begin{array}{l}\text { Member of the Board } \\
\text { of Directors }\end{array}$ & 73 & 30 \\
\hline & Administrator & 65 & 27 \\
\hline & Football team player & 102 & 43 \\
\hline \multicolumn{2}{|l|}{ Total } & 240 & 100 \\
\hline
\end{tabular}

Source: Private edition, 2018.

The study sample distribution by practical experience indicated that $23 \%$ of the study sample have less than 5 years of practical experience, and $48 \%$, ranging from 5 to less than 10 years, and $29 \%$, have above 10 years of practical experience. The study sample distribution by the academic level has revealed that $38 \%$ of respondents hold a Bachelor's degree, and that $49 \%$ are holding less than Bachelor Degree, and that $13 \%$ have obtained High- Level Degree. The study sample distribution depending on the type of the relationship with the club indicated that $30 \%$ of the study sample were Members of the Board of Directors and 27\% were working as administrators in the club and $43 \%$ who are the players of the first club team.

\subsection{Descriptive analysis results}

3.3.1 The administrative aspect 
In this section, we will analyze the data of the research sample and review the most important results of the questionnaire, through utilizing the averages, and the standard deviations of all research questions that measuring the degree of availability of the three aspects in order to answer the research mean question.

Descriptive analysis of the administrative aspects was used to assess the results obtained from the questionnaires and set out to provide an answer to the following sub-questions: What is the state of the administrative aspect of social responsibility practices in the football clubs of the professional league in Jordan, from the point of view of working members and players? Results are indicated as follows:
Table 5 indicates that the study sample perception regarding the availability degree of the administrative aspect Means ranged between $(2.49-2.89)$ with a Standard Deviation of $(1.29$ - 1.00) respectively. The Administrative aspect questions got responses that were mostly around the average and indicated that the respondents were mostly socially responsible. The results also showed that statement No. (18) " The club participates in social activities organized by the Ministry of Youth "ranked the first, while statement no. (10) " There are documented publications containing the tasks, duties, and programs of social responsibility in the club ranked the last. And the General Mean (2.70) confirms the medium degree of availability of the administrative factor for

Table 5: Means and Standard Deviations of Sample Responses Regarding the administrative aspect

\begin{tabular}{|c|c|c|c|c|c|}
\hline No & Statement & Mean & S.D & Rank & Degree \\
\hline 18 & The club participates in social activities organized by the Ministry of Youth. & 2.89 & 1.09 & 1 & Medium \\
\hline 10 & $\begin{array}{l}\text { Club facilities are suitable for the implementation of social responsibility } \\
\text { activities. }\end{array}$ & 2.88 & 1.20 & 2 & Medium \\
\hline 23 & The club is keen to use water conservation tools & 2.86 & 1.08 & 3 & Medium \\
\hline 22 & The club is interested in rationalizing the consumption of electricity & 2.84 & 1.14 & 4 & Medium \\
\hline 12 & $\begin{array}{l}\text { It is used in the player's celebrity in the implementation of programs of } \\
\text { social responsibility }\end{array}$ & 2.81 & 1.08 & 5 & Medium \\
\hline 5 & $\begin{array}{l}\text { There is a consensus between the objectives and programs of social responsi- } \\
\text { bility and the goals of the club. }\end{array}$ & 2.80 & 1.19 & 6 & Medium \\
\hline 3 & There is a declared goal of social responsibility of the club. & 2.79 & 1.17 & & Medium \\
\hline 13 & $\begin{array}{l}\text { The club uses materials and devices that do not adversely affect the environ- } \\
\text { ment (materials friendly to the environment). }\end{array}$ & 2.78 & 1.14 & 7 & Medium \\
\hline 1 & $\begin{array}{l}\text { There is an independent management department of social responsibility in } \\
\text { the club. }\end{array}$ & 2.78 & 1.18 & 8 & Medium \\
\hline 8 & $\begin{array}{l}\text { There are partnerships with specialized institutions, and bodies to develop } \\
\text { the management process of social responsibility in the club. }\end{array}$ & 2.70 & 1.29 & 9 & Medium \\
\hline 14 & $\begin{array}{l}\text { The club cooperates with local bodies and institutions to preserve the envi- } \\
\text { ronment. }\end{array}$ & 2.69 & 1.03 & 10 & Medium \\
\hline 9 & The club is keen to use tools and devices that can be recycled & 2.63 & 1.19 & 11 & Medium \\
\hline 19 & $\begin{array}{l}\text { There are periodic reports on social responsibility programs implemented by } \\
\text { the club. }\end{array}$ & 2.74 & 1.29 & 12 & Medium \\
\hline 2 & There are a vision and a mission for the social responsibility of the club. & 2.72 & 1.15 & 13 & Medium \\
\hline 4 & There is a measurable timeline for social club programs at the club. & 2.70 & 1.29 & 14 & Medium \\
\hline 17 & There is a promotional personality for social responsibility programs. & 2.67 & 1.03 & 15 & Medium \\
\hline 20 & The club makes a balance between social activities and sports activities & 2.63 & 1.19 & 16 & Medium \\
\hline 6 & There are full-time specialists for social activities at the club. & 2.62 & 1.00 & 17 & Medium \\
\hline 15 & $\begin{array}{l}\text { There are incentives for clubs that have effective initiatives in social respon- } \\
\text { sibility. }\end{array}$ & 2.60 & 1.11 & 18 & Medium \\
\hline 7 & There is a logo for social responsibility that shows its goals. & 2.57 & 1.29 & 19 & Medium \\
\hline 11 & $\begin{array}{l}\text { An icon is available at the club's own social club to advertise their pro- } \\
\text { grams. }\end{array}$ & 2.56 & 1.15 & 20 & Medium \\
\hline 16 & The club is keen to use tools and devices that can be recycled & 2.53 & 1.09 & 21 & Medium \\
\hline 21 & $\begin{array}{l}\text { The club takes into account the observations raised by the different institu- } \\
\text { tions of society regarding its social activities. }\end{array}$ & 2.50 & 1.08 & 22 & Medium \\
\hline 10 & $\begin{array}{l}\text { There are documented publications containing the tasks, duties, and pro- } \\
\text { grams of social responsibility in the club. }\end{array}$ & 2.49 & 1.23 & 23 & Medium \\
\hline \multicolumn{2}{|c|}{ General mean } & 2.70 & 1.15 & \multicolumn{2}{|c|}{ Medium } \\
\hline
\end{tabular}

Source: Private edition, 2018. 
implementing the CSR practices from the sample's subject's point of view.

\subsubsection{The financial aspect}

Descriptive analysis of the financial aspects was conducted to answer the following sub-question: What is the state of the financial aspect of social responsibility practices in the football clubs of the professional league in Jordan, from the point of view of working members and players?

Table (6): Means and Standard Deviations for Sample Responses Regarding the financial aspect

\begin{tabular}{|c|c|c|c|c|c|}
\hline No & Statement & Mean & S.D & Rank & Degree \\
\hline 24 & $\begin{array}{l}\text { There is a budget available for social } \\
\text { responsibility activities. }\end{array}$ & 3.03 & 1.20 & 1 & Medium \\
\hline 25 & $\begin{array}{l}\text { Members of honor in the club adopt } \\
\text { funding for social responsibility } \\
\text { programs. }\end{array}$ & 2.99 & 1.20 & 2 & Medium \\
\hline 28 & $\begin{array}{l}\text { There are sponsors for social respon- } \\
\text { sibility programs outside the club. }\end{array}$ & 2.98 & 1.19 & 3 & Medium \\
\hline 31 & $\begin{array}{l}\text { Support is available from the Minis- } \\
\text { try of Youth for social responsibility } \\
\text { programs. }\end{array}$ & 2.97 & 1.22 & 4 & Medium \\
\hline 26 & $\begin{array}{l}\text { A percentage of the games, ticket } \\
\text { sales income goes for programs of } \\
\text { social responsibility. }\end{array}$ & 2.95 & 1.18 & 5 & Medium \\
\hline 32 & $\begin{array}{l}\text { Some of the club's players are in- } \\
\text { volved in the funding of the collective } \\
\text { responsibility programs. }\end{array}$ & 2.89 & 1.88 & 6 & Medium \\
\hline 27 & $\begin{array}{l}\text { Charitable matches are held for the } \\
\text { social responsibility programs }\end{array}$ & 2.88 & 1.18 & 7 & Medium \\
\hline 29 & $\begin{array}{l}\text { A percentage of the broadcast } \\
\text { match's rights go for social responsi- } \\
\text { bility programs. }\end{array}$ & 2.87 & 1.14 & 8 & Medium \\
\hline 34 & $\begin{array}{l}\text { Sponsoring companies contribute to } \\
\text { the club in supporting social responsi- } \\
\text { bility programs. }\end{array}$ & 2.86 & 1.14 & 9 & Medium \\
\hline 33 & $\begin{array}{l}\text { There are a percentage of club } \\
\text { sales such as player shirts for social } \\
\text { responsibility programs. }\end{array}$ & 2.85 & 1.12 & 10 & Medium \\
\hline 34 & $\begin{array}{l}\text { A percentage of the value of a profes- } \\
\text { sional player's contract is allocated to } \\
\text { social responsibility programs. }\end{array}$ & 2.84 & 1.24 & 11 & Medium \\
\hline \multicolumn{2}{|c|}{ General mean } & 2.91 & 1.24 & \multicolumn{2}{|c|}{ Medium } \\
\hline
\end{tabular}

Source: Private edition, 2018.

Table 6 indicates that the study sample perception regarding the availability degree of the financial aspect means ranged between $(2.84-3.03)$ with a standard deviation of $(1.88-1.12)$ respectively. The financial aspect questions got responses that were mostly around the average and indicated that the respondents were mostly socially responsible. The results also showed that statement No. (24)" There is a budget available for social responsibility activities "ranked the first, while statement No (34)" A percentage of the value of professional player's contracts is allocated to social responsibility programs "ranked the last, In addition, the General Mean (2.91) confirms the medium degree of availability for the financial factor in implementing the CSR practices from the sample's subject's point of view.

\subsubsection{The CSR Programs}

Descriptive analysis was conducted to answer the following sub-questions: What is the state of the CSR programs which provided by the football clubs of the professional league in Jordan, from the point of view of working members and players?

Table (7): Means and Standard Deviations of Sample Responses Regarding the CSR provided programs

\begin{tabular}{|c|c|c|c|c|c|}
\hline No & Statement & Mean & S.D & Rank & Degree \\
\hline 13 & $\begin{array}{l}\text { There are programs offered at reli- } \\
\text { gious, national and sporting events. }\end{array}$ & 3.10 & 1.15 & 1 & Medium \\
\hline 7 & $\begin{array}{l}\text { There are programs targeting } \\
\text { orphans. }\end{array}$ & 2.92 & 1.12 & 2 & Medium \\
\hline 9 & There are programs for youth. & 2.91 & 1.14 & 3 & Medium \\
\hline 4 & $\begin{array}{l}\text { There are joint programs with gov- } \\
\text { ernment institutions. }\end{array}$ & 2.88 & 1.24 & 4 & Medium \\
\hline 2 & $\begin{array}{l}\text { There are various programs to } \\
\text { enhance the sport culture. }\end{array}$ & 2.84 & 1.18 & 5 & Medium \\
\hline & $\begin{array}{l}\text { There are various programs to raise } \\
\text { the level of health awareness. }\end{array}$ & 2.83 & 1.10 & 6 & Medium \\
\hline 10 & $\begin{array}{l}\text { There are programs targeted the } \\
\text { school's students. }\end{array}$ & 2.82 & 1.08 & 7 & Medium \\
\hline 6 & There are programs for children. & 2.81 & 1.11 & 8 & Medium \\
\hline 8 & $\begin{array}{l}\text { The club maintains programs to } \\
\text { enhance intellectual security. }\end{array}$ & 2.80 & 1.24 & 9 & Medium \\
\hline 12 & $\begin{array}{l}\text { There are programs to reduce sports } \\
\text { violence. }\end{array}$ & 2.78 & 1.19 & 10 & Medium \\
\hline 1 & $\begin{array}{l}\text { There are training programs for mem- } \\
\text { bers of the community outside the club. }\end{array}$ & 2.75 & 1.09 & 11 & Medium \\
\hline 7 & $\begin{array}{l}\text { There are programs targeting club } \\
\text { staff members. }\end{array}$ & 2.74 & 1.06 & 12 & Medium \\
\hline 5 & $\begin{array}{l}\text { Design programs targeting people } \\
\text { with special needs. }\end{array}$ & 2.73 & 1.11 & 13 & Medium \\
\hline 14 & $\begin{array}{l}\text { There are environmental awareness } \\
\text { programs. }\end{array}$ & 2.72 & 1.13 & 14 & Medium \\
\hline 11 & $\begin{array}{l}\text { There are programs directed to club } \\
\text { fans and supporter. }\end{array}$ & 2.70 & 1.19 & 15 & Medium \\
\hline \multicolumn{2}{|c|}{ General mean } & 2.84 & 1.28 & \multicolumn{2}{|c|}{ Medium } \\
\hline
\end{tabular}

Source: Private edition, 2018.

Table 7 indicates that the study sample perception regarding the availability degree of CSR programs provided by the selected football clubs, Means ranged between $(2.70$ - 3.10) with a Standard Deviation of $(1.28$ - 1.08) respectively. The CSR programs questions got responses that were mostly around the average and indicated that the respondents were mostly socially responsible. The results also showed that statement no. (13) "There are programs offered at religious, national and sporting events "ranked the first, while statement no. (11) “ There are programs directed to club fans" ranked the last. And the general mean (2.84) confirms the medium degree of availability 
of CSR programs provided by selected sports clubs from the sample's subject's point of view.

Table.8. Total percentage of Means and Standard Deviations of Sample Responses in descending order

\begin{tabular}{|l|l|c|c|c|c|}
\hline No & The Aspect & Mean & S.D & Rank & $\begin{array}{c}\text { Degree of } \\
\text { Availability }\end{array}$ \\
\hline 1 & The Financial Aspect & 2.91 & 1.24 & 1 & Medium \\
\hline 2 & $\begin{array}{l}\text { The Programs } \\
\text { provided }\end{array}$ & 2.84 & 1.28 & 2 & Medium \\
\hline 3 & $\begin{array}{l}\text { The Administrative } \\
\text { Aspect }\end{array}$ & 2.70 & 1.15 & 3 & Medium \\
\hline Total & 2.82 & 1.2 & - & Medium \\
\hline \multicolumn{5}{|r|}{ Source: Private edition, 2018. } \\
\hline
\end{tabular}

Table 8 shows that the sample's perception on the state of CSR practices mean ranged between (2.70-2.91) with an average degree (2.82), and confirm the medium degree of availability of CSR practices in the football clubs of the professional football league in Jordan, also showed that the financial aspect ranked the first and the programs offered ranked the second while the administrative aspect ranked the last. Overall, the research results indicated that the main research question regarding the current state of CSR in the football clubs of the professional football league in Jordan got responses that were mostly around the average and revealed that the respondents were mostly socially responsible.

\section{CONCLUSIONS}

Social responsibility in the field of sport is still a new concept and received a little attention in CSR literature, so this research may be considered as a preliminary attempt to gain a comprehensive understanding of CSR current practices in the football clubs of the professional football league in Jordan from the point of view of board member's, administrators and players. The study revealed the following results for the research sub-questions in order to answer the main research question, which is stated as what is the current state of CSR practices in the football clubs of the professional football league in Jordan?

- Regarding the sub-question about the availability degree of the financial aspect in the selected football clubs, the results indicate that the financial aspect mean ranged between $(2.84-3.03)$ with a standard deviation of $(1.88-1.12)$, and the general mean (2.91) which is mostly around the average from the sample's subject's point of view, and it shows that the financial aspect ranked at the first as the most important factor that enhances and activate the CSR practices where the sport clubs determine its financial ability, its products, and services to support its CSR initiatives, with respect to the limited resources.

- Regarding the sub-question about the availability de- gree of CSR programs provided by the selected football clubs, the study sample perception shows that the availability degree of CSR programs provided by the selected clubs ranked the second, and the mean ranged between $(2.70-3.10)$ with a standard deviation of $(1.28$ - 1.08)And the general mean (2.84) which confirms the medium degree of availability of CSR programs as the sample's agreement on CSR practices, also it shows the interest of the football clubs in implementing the CSR activities to serve their communities.

- Regarding the sub-question about the availability degree of the administrative aspect in the selected football clubs, the study shows that the administrative aspect ranked the third and, the mean ranged between (2.49 $2.89)$ with a standard deviation of $(1.29-1.00)$, and the general mean (2.70). The administrative aspect questions got responses that were mostly around average and indicated that the respondents were mostly socially responsible, as the sample's subject's point of view stressed the importance of considering the Administrative aspect in managing CSR activities in football clubs.

Overall, the sample's perception on the current state of CSR practices in the football clubs of the professional football league in Jordan, shows that the mean ranged between (2.70-2.91) with an average degree (2.82) which confirms the medium degree of availability of the three aspects that promote the process of CSR implementation and express the importance of considering those aspects in managing CSR in football clubs from the sample's subject's point of view. In addition, the results show a little different in the ratio of degrees among the three aspects, where is the degree of availability of the administrative aspect as the last factor that enhance the implementation process of CSR is not far away from the rates of other aspects and all degrees stayed within the same average of availability. Furthermore, it shows that the respondents were mostly socially responsible where the Board members, administrator, and players were relatively concerned with the social responsibility concept. This may be attributed to the society who views sport clubs as social organizations that should priorities the social needs of the society.

The results revealed that there is a recognition of the concept of social responsibility by the board member's, administrators and players of the selected football clubs and they are aware of their social responsibility towards their society and surrounding environment, which consistent with other research studies on CSR in Jordan, such as the study of the (VISION INSTITUTE, 2014) and (ALDMOUR AND ASKAR, 2011). It's clear that more and more Jordanian stakeholders are becoming aware of the CSR concept and some organizations in Jordan are working their way towards strategizing $\mathrm{CR}$ efforts. In fact, the findings of the study provided support for the existence of CSR practices among the Jordanian sport clubs, on the contrary to the previous studies revealed that the concept of CSR was new in Jordan (ELIAN, 2005). 


\section{REFERENCES:}

1. Alfaisaly Club, (2017), Pages From History, Available At Https:/Www.alfaisalyscjo.com/Category/History/ (Accessed In.02.09.2018)

2. Akanse Burcak. Ates Evrim. Tapan Pinan \& Ozden Yasemin. (2010): Implementation Of Csr At European Football Clubs. Fifa/Cies Program In Sport Management, Bahcesehir University: Istanbul.

3. Al-Qarny. H. (2014), The Reality Of Social Responsibility In The Association Of Professional

Leagues In Saudi Arabia. Master Thesis, Sport Pedagogy Dept., Umm Alqura University, Saudia Arabia

4. Al Sadd Sport Club, Csr Statement Available At Http://AlSaddclub.com/The-Club/Social-Responsibility/

5 Babiak, K., \& Wolfe, R. (2009): Determinants Of Corporate Social Responsibility In Professional Sport: Internal And External Factors. Journal Of Sport Management, 23(3),

6. Bácsné Bába É. (2015): Examination Of The Organizational Frameworks Of Sports Enterprises In The Light Of Good German Practices. Apstract - Applied Studies In Agribusiness And Commerce 9:(1-2) Pp. 41-46.

7. Breitbarth, T., \& Harris, P. (2008): The Role Of Corporate Social Responsibility In The Football Business: Towards The Development Of A Conceptual Model. European Sport Management Quarterly, 8(2), 179-206.

8. Elian Khalil (2005): The State Of Corporate Social Responsibility In Jordan: Case Studies From Major Business Sectors, Amman, Jordan: Al-Urdun Aljadid Research Center (Ujrc).

9. Hani H. Al-Dmour And Hayat A. Askar (2011): The Impact Of Corporate Social Responsibility On Companies Perceived Performance: A Comparative Study Between Local And Foreign Companies In Jordan, Journal Of Business Administration, Volume 7, And No. 1, 2011

10. Héder M. - Dajnoki K. (2017): Connection Of Talent And Career Management - Differences And Similarities. Network Intelligence Studies Vol. 5.:(Issue 9.) Pp. 57-66.

11. Jordan Football Association. Football: A Jordanian Passion Available At Http://Www.jfa.com.jo/En/About/ Accessed In.02.13.2018

12. Jordan Premier League Https: Available At//En.wikipedia. org/Wiki/Jordan_premier_league) Accessed In.03.13.2018

13. Maignan. I, Ferrell O. C. (2004): Corporate Social Responsibility And Marketing: An Integrative Framework, Journal Of The Academy Of Marketing Science. Volume 32, No. 1, Pages 3-19.

14. Ministry Of Youth, (2005) .Sport Clubs Registration And License Regulations (2005) Available At: Organizationshttp:// Www.moy.gov.jo/Node/80 Accessed In.03.14.2018

15. Misener, L. \& Mason, D. (2006). Community Networks: Can Sporting Events Offer Meaningful Sources Of Social Capital? Managing Leisure, 11(1), 39-56.

16. Rosca, V, (2011): Corporate Social Responsibility In English Football: History And Present Vlad Roşca Academy Of Economic Studies, Bucharest Piaţa Romană No. 6, Bucharest, România

17. Saunders Mark, Lewis Philip, Thornhill Adrian, (2009) Research Methods For Business Students, Fifth Edition,
18. Sheth, H., \& Babiak, K. (2009): Beyond The Game, Perceptions And Practices Of Corporate Social Responsibility In The Professional Sport Industry. Journal Of Business Ethics. Content/Http://Www.springerlink.com/ Accessed In.02.17.2018

19. Smith, A.c.t., \& Westerbeek, H.m. (2007): Sport As A Vehicle For Deploying Social Responsibility. Journal Of Corporate Citizenship, 25(Spring), 43-54.

20. The Federation International De Football Association (Fifa.2007). For The Game. For The World: New Fifa Slogan Brings Social Responsibility To The Fore, Viewed 25 May 2018 Http://Cutt.us/8Wp5b. Accessed In.02.28.2018

21. The Meras Center For Management Consultancy (2010), The Guidelines Manual For Policies And Procedures Of Social Responsibility Programs, Alriyadh Council For Csr, 2010 Available At Https://Tslibrary.org/601 (Accessed In.03.09.2018)

22. United Nations (2005). A Year For Sport: Sport And The Millennium Development Goals. Available From: Http:// Www.un.org/Sport2005/A year/Mill goals.html (Accessed On 03.12.2018)

23. Schwab, K. (2008). Global Corporate Citizenship: Working With Governments And Civil Society, Foreign Affairs, Jan-Feb 2008, 107-118.

24. United Nations (2009). Millennium Development Goals. Available From:http://Www.un.org/Millenniumgoals (Accessed On 03.17.2018)

25. Vision Institute For Civil Society Studies 2014: Corporate Social Responsibility In Jordan Current Status And Future Prospects, Survey Analysis Of Jordan Ceo Perception Of Csr, 2 2014, Vision Institute For Civil Society Studies, Amman. Jordan

26. Zeigler, E.f. (2007): Sport Management Must Show Social Concern As It Develops Tenable Theory. Journal Of Sports Management, 21 (2009), 297-318. 
